\title{
Modeling of allergen proteins found in sea food products
}

\author{
Modelagem de proteínas alergênicas em frutos do mar
}

Nataly GALÁN-FREYLE ${ }^{1}$ Jesús OLIVERO-VERBEL ${ }^{1 *}$, Liney DÍAZ-LÓPEZ ${ }^{1}$

\begin{abstract}
Shellfish are a source of food allergens, and their consumption is the cause of severe allergic reactions in humans. Tropomyosins, a family of muscle proteins, have been identified as the major allergens in shellfish and mollusks species. Nevertheless, few experimentally determined three-dimensional structures are available in the Protein Data Base (PDB). In this study, 3D models of several homologous of tropomyosins present in marine shellfish and mollusk species (Chaf 1, Met e1, Hom a1, Per v1, and Pen a1) were constructed, validated, and their immunoglobulin E binding epitopes were identified using bioinformatics tools. All protein models for these allergens consisted of long alpha-helices. Chaf 1, Met e1, and Hom a1 had six conserved regions with sequence similarities to known epitopes, whereas Per v1 and Pen al contained only one. Lipophilic potentials of identified epitopes revealed a high propensity of hydrophobic amino acids in the immunoglobulin E binding site. This information could be useful to design tropomyosin-specific immunotherapy for sea food allergies.

Keywords: tropomyosin; IgE cross-reactivities; allergen.
\end{abstract}

\section{Resumo}

Os mariscos são fontes de alérgenos alimentares e seu consumo é a causa de graves reações alérgicas em humanos. Tropomiosinas, uma família de proteínas musculares, foram identificadas como os principais alérgenos em espécies de crustáceos e moluscos. No entanto, poucas estruturas experimentais tridimensionais estão disponíveis no Protein Data Base (PDB). Neste trabalho, modelos 3D de vários homólogos de tropomiosinas presentes em moluscos marinhos e espécies de moluscos (Chaf 1, Met e1, Hom a1, v1 Per e Pen a1) foram construídas, validadas e seus epítopos de ligação de imunoglobulina E (IgE) foram identificados, utilizando ferramentas de bioinformática. Todos os modelos de proteína para esses alérgenos consistiam em longas alfa-hélices. Chaf 1, Met e1, e Hom al apresentaram seis regiões conservadas com similaridades de sequência para epítopos conhecidos, enquanto v1 Per e Pen al único. Potenciais lipofílicos de epítopos identificados revelaram uma alta propensão de aminoácidos hidrofóbicos em sítio de ligação IgE. Esta informação poderia ser útil para projetar imunoterapia específica para tropomiosina para alergias alimentares.

Palavras-chave: tropomiosina; IgE reação cruzada; alérgeno.

\section{Introduction}

Shellfish is a broad term that encompasses all aquatic animals that have a shell or shell-like exoskeleton. In general, shellfish are separated into two basic categories, namely crustaceans and mollusks. Shellfish are not only an important food source for humans, but also a frequent cause of adverse food hypersensitivity, which is commonly associated with IgE-mediated immediate-type I allergy (LU et al., 2007; AYUSO; LEHRER; REESE, 2002). Crustaceans (shrimp, crab, and lobster) are recognized as a common cause of food hypersensitivity reactions that include oropharyngeal pruritus, urticaria, angioedema, gastrointestinal distress, and anaphylaxis (DAUL; MORGAN; LEHRER, 1993; MUSMAND; DAUL; LEHRER, 1993). Similar adverse reactions have been described in patients consuming mollusks such as oysters (LEHRER et al., 1987).

The major allergen identified in shrimp is the muscle protein tropomyosin. In fact, at least $80 \%$ of shrimp-allergic subjects react to tropomyosin. This allergen is also present in other crustaceans such as lobsters and crabs, as well as in mollusks (AYUSO; LEHRER; REESE, 2002).

Considerable experimental and computational studies have been conducted to characterize the sequences and substructures of food allergens that could account for cross-reactivity in sensitive individuals (FEDOROV et al., 1997; FERREIRA et al., 1998; BRUSIC; PETROVSKY, 2003; BREITENEDER; MILLS, 2005; JENKINS et al., 2005). A common approach is to analyze the structure of allergy-producing agents and to predict antigenic determinants as well as cross-reactive determinants using bioinformatics tools. This provides an insight into the molecular basis of allergenicity and helps to elucidate the biological function of allergens (WESTBROOK et al., 2003). The objective of the present study is to model and determine the potential allergenicity of some known allergens present

\footnotetext{
Received 28/5/2011

Accepted 8/11/2011 (005315)

${ }^{1}$ Environmental and Computational Chemistry Group, Faculty of Pharmaceutical Sciences, University of Cartagena, Campus of Zaragocilla, Cartagena, Colombia, e-mail: joliverov@unicartagena.edu.co; jesusolivero@yahoo.com

${ }^{*}$ Corresponding author
}

http://dx.doi.org/10.1590/S0101-20612012005000032 
in shellfish including Cha f1 (Charybdis feriatus), Hom a1 (Homarus americanus), Met e1 (Metapenaeus ensis), Pen a1 (Farfantepenaus), Per v1 (Perna viridis), and Cra g1 (Crassostrea).

\section{Materials and methods}

Amino acid sequences for Tropomyosins were obtained from the National Center for Biotechnology Information (2010). Basic information for each one of the studied allergens is presented in Table 1.

Three dimensional models of shellfish-derived tropomyosins were obtained using the molecular modeling package SYBYL 8.1.1 (TRIPOS, 2008) (with license belonging to the Environmental and Computational Chemistry Group), as well as free-available servers such as I-TASSER (ROY; KUCUKURAL; ZHANG, 2010) and SwissModel (SCHWEDE et al., 2003).

The SYBYL model was generated using the FUGUE tool incorporated in the Biopolymer module. FUGUE recognized distant structural homologs of tropomyosins by sequence structure comparison. After this process, the ORCHESTRAR interface in SYBYL allowed the sequence alignment of the homologs to model conserved regions (main chain). Loop conformations were automatically generated by the program, and subsequently the side chains and hydrogens were added to the models. Generated models were refined using the AMBER7 FF99 force field after several minimizations.

The I-TASSER and the SwissModel servers provide a fully automated comparative and threading protein modeling. These serves requires only the amino acid sequence as input data to generate the 3D model. Template selection, alignment, and model building are automatically performed by the server (ZHANG, 2008).

The stereochemical quality of the obtained 3D models were evaluated utilizing a set of different servers, such as PROCHECK program (LASKOWSKI et al., 1993), ERRAT (COLOVOS; YEATES, 1993), VERIFY 3D (EISENBERG; LÜTHY; BOWIE, 1997), PROSA (WIEDERSTEIN; SIPPL, 2007), and WHATCHECK program (HOOFT et al., 1996).

The Structural Database of Allergenic Proteins, SDAP (IVANCIUC et al., 2003) was used to find reported epitope sequences for studied shellfish allergens (SCHEIN; IVANCIUC; BRAUN, 2005; IVANCIUC et al., 2003; SCHEIN; IVANCIUC; BRAUN, 2006). SDAP has integrated search tools that allow the user to rapidly compare molecular properties of allergenic proteins and their epitopes. Those allergens, for which no information is present on SDAP, were scanned for epitope prediction using the allergenicity prediction server AlgPred. This server was employed to find IgE-binding regions that were not identified in the SDAP database. AlgPred scans for known IgE epitopes using a BLAST search, based on amino acid or on dipeptide
Table 1. Name, source, and accession number for studied tropomyosins.

\begin{tabular}{ccc}
\hline Allergen & $\begin{array}{c}\text { Species } \\
\text { (Common name) }\end{array}$ & $\begin{array}{c}\text { Accession } \\
\text { number }\end{array}$ \\
\hline Cha f 1 & $\begin{array}{c}\text { Charybdis feriatus } \\
\text { (Crab) }\end{array}$ & Q9N2R3 \\
Cra g 1 & $\begin{array}{c}\text { Crassostrea gigas } \\
\text { (Pacific Oyster) }\end{array}$ & 15419048/Q95WY0 \\
Hom a 1 & $\begin{array}{c}\text { Homarus americanus } \\
\text { (American Lobster) }\end{array}$ & 2660868/O44119 \\
Met e 1 & $\begin{array}{c}\text { Metapenaeus ensis } \\
\text { (Shrimp) }\end{array}$ & Q25456 \\
Pen a 1 & $\begin{array}{c}\text { Farfantepenaus aztecus } \\
\text { (Shrimp) }\end{array}$ & Q3Y8M6 \\
Per v 1 & $\begin{array}{c}\text { Perna viridis } \\
\text { (Tropical green mussel) }\end{array}$ & 9954251/Q9GZ70 \\
\hline
\end{tabular}

composition, applying a hybrid approach that combines several procedures (SAHA; RAGHAVA, 2006).

Once obtained the list of epitopes (either from the database or predicted) from each one of the studied allergens, the PD tool incorporated in the SDAP website was employed to calculate PD values for these sequences. PD values measure the similarity of two peptides based on the physicochemical properties (PCPs) of corresponding residues when they are aligned with each other. Each residue is represented by five numerical descriptors E1-E5, which were derived by multidimensional scaling of a set of 237 PCPs of amino acid side chains (SAHA; RAGHAVA, 2006; SCHEIN; IVANCIUC; BRAUN, 2005). Peptides with identical sequences have a $\mathrm{PD}$ value of 0 , and peptides with conservative substitutions of few amino acids have small $P D$ values, typically in the range of 0 to 3 . Peptides with a recognizable similarity in their PCPs tend to have PD values lower than 10 , while unrelated peptides have much higher PD values (VENKATARAJAN; BRAUN, 2001). The output of the PD tool also offers a list of other allergens with similar sequences to those that have been analyzed (IVANCIUC et al., 2004).

Lipophilic potentials (LP), a measure of the relative hydrophobic surface area of a peptide, were generated using the MOLCAD module in SYBYL 8.1.1 with default probe radius of $1.4 \AA$. The resulting LP maps were analyzed according to color ramps (SCHEIN; IVANCIUC; BRAUN, 2007).

\section{Results}

The quality and validation data for all 3D models generated for the allergens, evaluated by different servers, are presented in Table 2. Based on validation data, I-Tasser models were the most energetically and geometrically favorable. These were visualized using the PyMOL software showing their known (SDAP) or predictive (AlgPred) epitope sequences (Figure 1). 


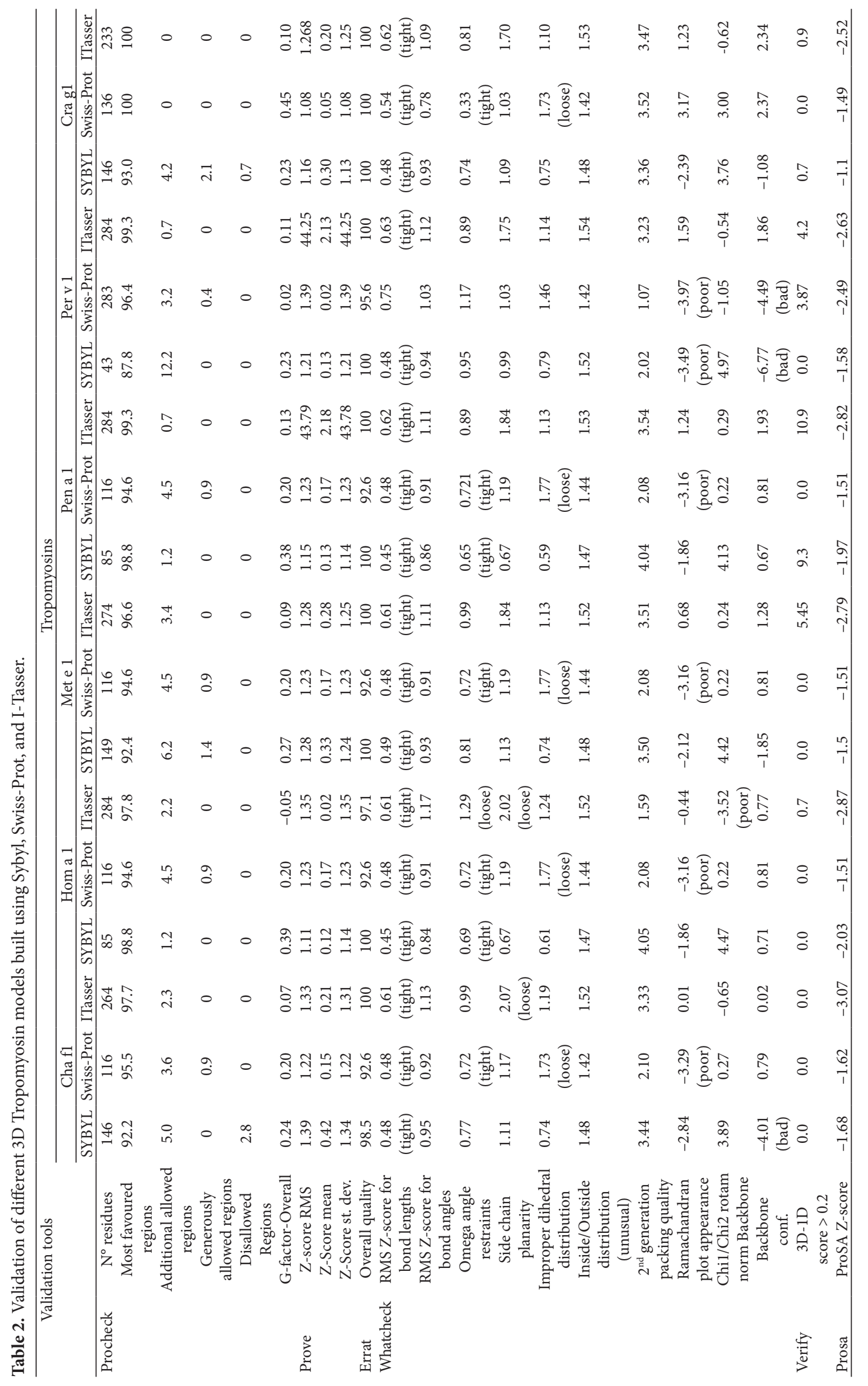



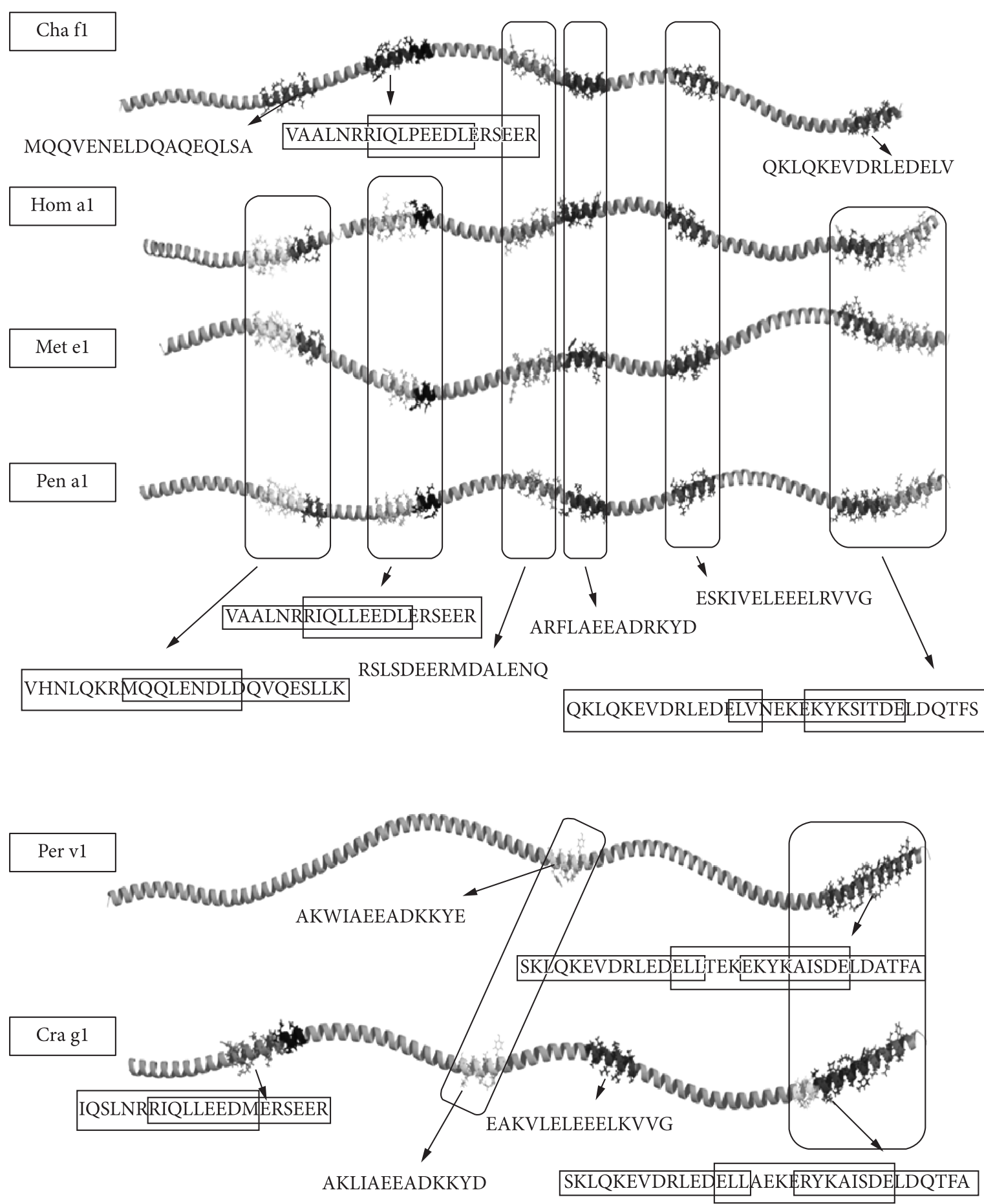

Figure 1. Tridimensional structures of tropomyosin allergens (Cha f1, Hom a1, Met e1, Pen a1, Per v1, and Cra g) modeled by I-Tasser server showing the position of epitopes as predicted by Algpred. Vertical boxes include identical epitopes between the models.

All allergen structures are mostly alpha helices, and some have a small portion of random structures.

The epitope sequences identified in each one of the studied allergens and the degree of similarity with sequences present in the SDAP database were evaluated using the PD score. These results, as well as those obtained for other seafood-related allergens (Pan s1, Spiny lobster; Lit v1, Whiteleg shrimp; Hal d1, Abulón; and Mim n1, Scallop), identified as having similar sequences to those evaluated in this study, are presented in Table 3.

As shown in Figure 1, there are different epitope sequences within the same allergen. In order to gain insight in the nature of these allergenic sequences, lipophilic potentials were calculated for those epitopes found in Hom a1, Met e1, and Pen a1. These results are shown in Figure 2. 
${ }^{43} \mathrm{VHNLQKRMQQLENDLDQVQESLLK}{ }^{66}$

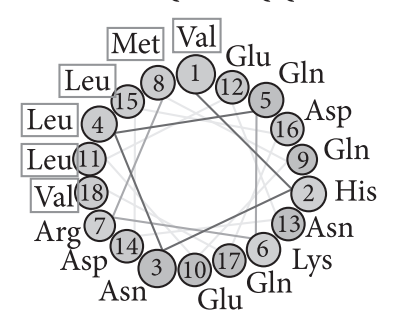

${ }^{85}$ VAALNRRIQLLEEDLERSEER ${ }^{105}$

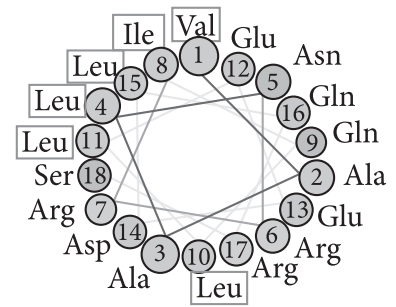

${ }^{133}$ RSLSDEERMDALENQ ${ }^{147}$

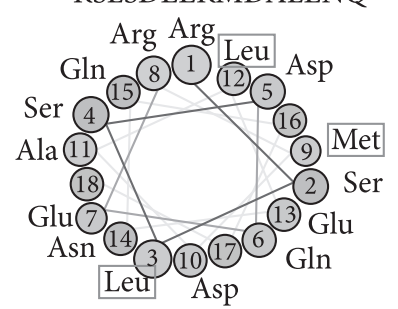

${ }^{151}$ ARFLAEEADRKYD ${ }^{163}$

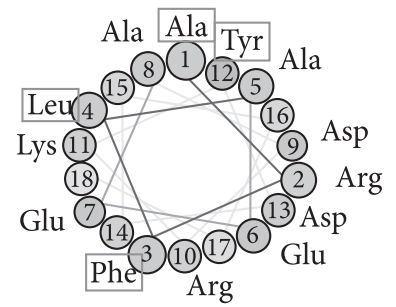

${ }^{187}$ ESKIVELEEELRVVG ${ }^{201}$

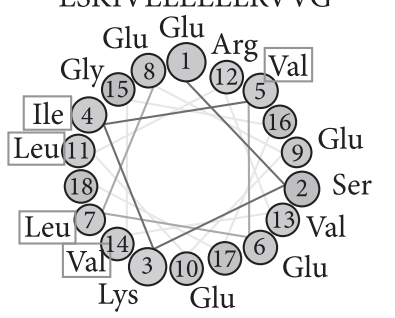

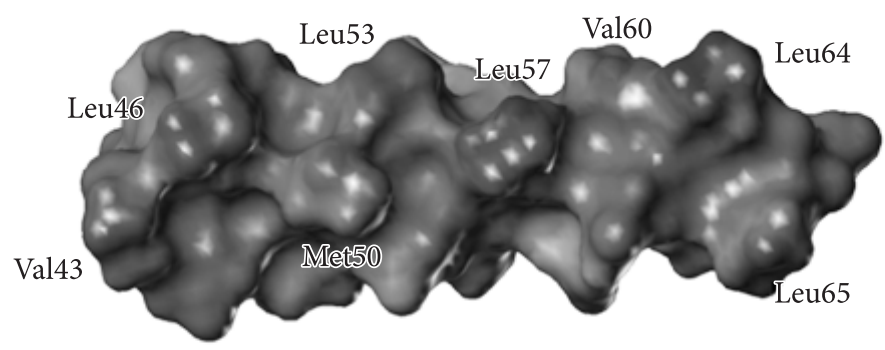
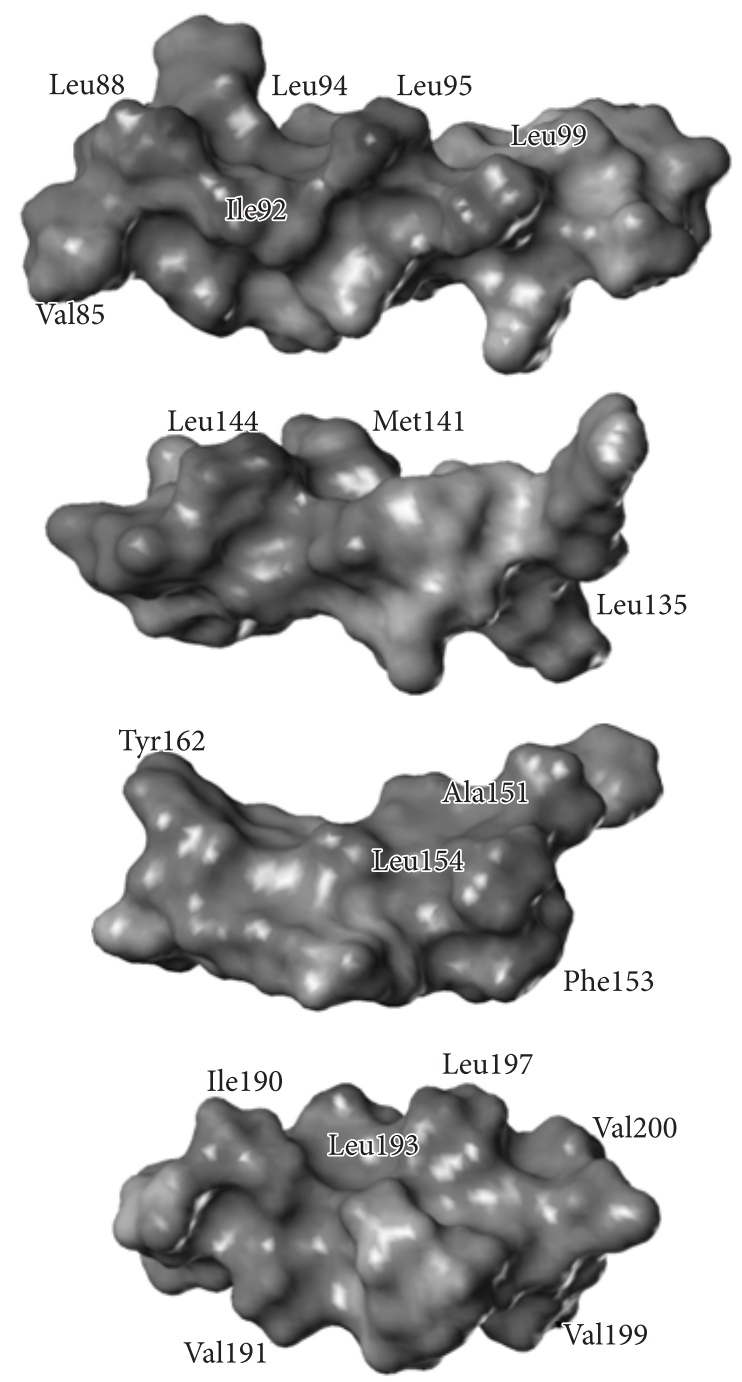

${ }^{247} \mathrm{QKLQKEVDRLEDELVNEKEKYKSITDELDQTFS}{ }^{279}$
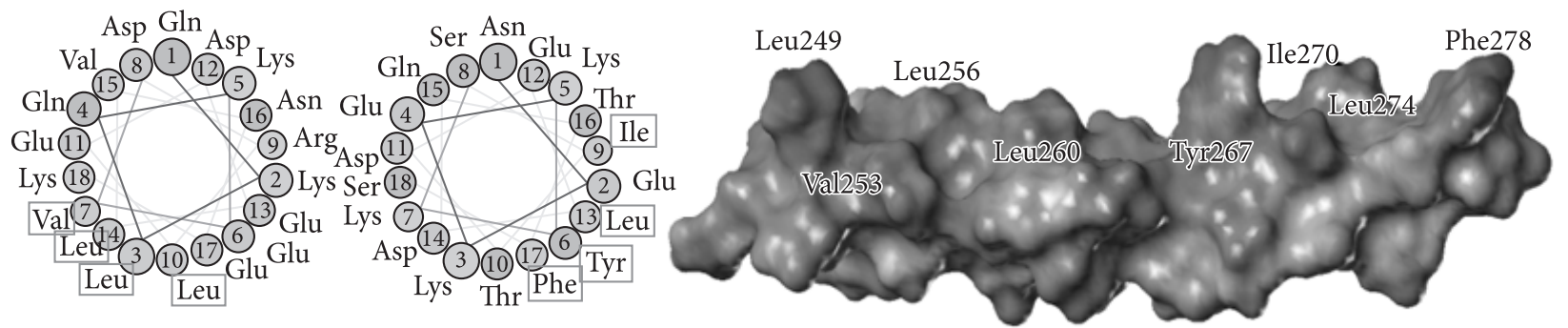

Figure 2. Helical-wheel representations of sequences and lipophilic potential surfaces of common epitopes in the models of tropomyosins. Potential surfaces were generated using the MOLCAD module in Sybyl 8.1.1., and the helical-wheel representations utilizing Applet (http://cti. itc.virginia.edu/ cmg/Demo/wheel/wheelApp.html). 
Table 3. PD scores generated after comparing allergen sequences detected in studied seafood allergens (SDAP database and AlgPred). PD scores for other seafood-related allergens having high sequence similarities with those modeled are presented in the right side of the table.

\begin{tabular}{|c|c|c|c|c|c|c|c|c|c|c|}
\hline Sequences & Cha f1 & Hom a1 & Met e1 & Pen al & Perv1 & Cra g1 & Pan s1 & Lit v1 & Hal d1 & $\operatorname{Mim} n 1$ \\
\hline ARFLAEEADRKYD & 0.00 & 0.00 & 0.00 & 0.00 & 3.19 & 2.43 & 0.00 & 0.00 & 3.72 & 7.50 \\
\hline ESKIVELEEELRVVG & 0.00 & 0.00 & 0.00 & 0.00 & 9.20 & 2.44 & 0.50 & 0.00 & 2.08 & 3.69 \\
\hline MQQVENELDQAQEQLSA & 0.00 & 5.39 & 5.39 & 5.39 & $>10$ & $>10$ & 5.39 & 5.39 & 7.58 & 8.19 \\
\hline QKLQKEVDRLEDELV & 0.00 & 0.00 & 0.00 & 0.00 & 1.41 & 1.41 & 0.00 & 0.00 & 1.41 & 2.03 \\
\hline RIQLPEEDLERSEER & 0.00 & 1.75 & 1.75 & 1.75 & 7.48 & 2.51 & 1.75 & 1.75 & 3.46 & 4.65 \\
\hline RSLSDEERMDALENQ & 0.00 & 0.00 & 0.00 & 0.00 & 8.30 & 8.97 & 0.00 & 0.00 & 4.78 & 6.03 \\
\hline VAALNRRIQLPEEDL & 0.00 & 1.75 & 1.75 & 1.75 & 7.91 & 4.93 & 1.75 & 1.75 & 7.11 & 7.22 \\
\hline EKYKSITDELDQTFS & $>10$ & 0.00 & 0.00 & 0.00 & 3.50 & 2.93 & 0.00 & 0.00 & 2.45 & 3.63 \\
\hline ELVNEKEKYKSITDE & $>10$ & 0.00 & 0.00 & 0.00 & 2.75 & 3.74 & 0.00 & 0.00 & 3.26 & 4.43 \\
\hline MQQLENDLDQVQESLLK & 5.39 & 0.00 & 0.00 & 0.00 & 8.83 & $>10$ & 0.00 & 0.00 & 6.49 & 8.49 \\
\hline VDRLEDELVNEKEKY & 8.92 & 0.00 & 0.00 & 0.00 & 1.31 & 2.29 & 0.00 & 0.00 & 1.81 & 2.29 \\
\hline VHNLQKRMQQLENDL & 5.45 & 0.00 & 0.00 & 0.00 & 6.17 & 6.17 & 0.00 & 0.00 & 5.09 & 6.40 \\
\hline AKWIAEEADKKYE & 3.19 & 3.19 & 3.19 & 3.19 & 0.00 & 2.14 & 3.19 & 3.19 & 3.74 & 9.25 \\
\hline EKYKAISDELDATFA & 8.72 & 3.50 & 3.50 & 3.50 & 0.00 & 1.53 & 3.50 & 3.50 & 1.05 & 2.22 \\
\hline ELLTEKEKYKAISDE & 9.77 & 2.75 & 2.75 & 2.75 & 0.00 & 1.36 & 2.75 & 2.75 & 0.88 & 2.05 \\
\hline SKLQKEVDRLEDELL & 1.41 & 1.41 & 1.41 & 1.41 & 0.00 & 0.00 & 1.41 & 1.41 & 0.00 & 1.45 \\
\hline VDRLEDELLTEKEKY & 8.99 & 1.31 & 1.31 & 1.31 & 0.00 & 1.36 & 1.31 & 1.31 & 0.88 & 1.36 \\
\hline AKLIAEEADKKYD & 2.43 & 2.43 & 2.43 & 2.43 & 2.14 & 0.00 & 2.43 & 2.43 & 3.53 & 9.24 \\
\hline ERYKAISDELDQTFA & 9.36 & 2.93 & 2.93 & 2.93 & 1.53 & 0.00 & 2.93 & 2.93 & 0.48 & 0.69 \\
\hline ELLAEKERYKAISDE & 9.86 & 3.74 & 3.74 & 3.74 & 1.36 & 0.00 & 3.74 & 3.74 & 0.48 & 0.69 \\
\hline EAKVLELEEELKVVG & 2.44 & 2.44 & 2.44 & 2.44 & 3.00 & 0.00 & 2.85 & 2.44 & 0.36 & 1.79 \\
\hline IQSLNRRIQLLEEDM & 4.93 & 3.18 & 3.18 & 3.18 & 4.03 & 0.00 & 3.18 & 3.18 & 5.75 & 5.36 \\
\hline VDRLEDELLAEKERY & 9.33 & 2.29 & 2.29 & 2.29 & 1.36 & 0.00 & 2.29 & 2.29 & 0.48 & 0.00 \\
\hline
\end{tabular}

\section{Discussion}

The geometries of the 3D models for the studied tropomyosins were evaluated using different bioinformatic tools. One of the most frequently used tool is PROCHECK, a server that utilizes information extracted from the Ramachandran's plot calculations. For most models, residues were mainly located on permitted regions. However, the overall G-factor calculated for the I-Tasser models showed values closer to 0 suggesting a good reliability for them (FÁVERO et al., 2009). ERRAT, an "overall quality factor", works by analyzing the statistics of non-bonded atom - atom interactions. For the studied allergens, ERRAT scores were large, and both SYBYL and I-Tasser models provided the best results with several cases showing 100\% indicating a good protein environment (ANURADHA et al., 2010). However, WHATCHECK revealed that the RMS Z-score for bond lengths, RMS Z-score for bond angles, omega angle restraints, side chain planarity, and improper dihedral distribution for the modeled structures were all positive representing a better conformation of the protein (positive is better than average) (YANG et al., 2008); therefore there is a normal distribution of residue types inside and outside the protein.

The analyses of the compatibility of the atomic models (3D) with its own amino acid sequence (1D) using the server
Verify 3D, computed several 3D-1D scores with values lower than 0.1 , indicating a possible problem. However, when this score factor was computed for 1clg-chain A, a protein that was used as template to generate Sybyl models, a low value was also obtained. This could be due to the simplicity of the structure and its propensity to behave as alpha helices. In general, the best 3D-1D scores were obtained for I-Tasser models. On the other hand, the ProSA-Web server showed that the Z-score values for the I-TASSER-generated models are appropriate. Negative scores for the modeled proteins indicated they are correct. In addition, those fall within the range of scores obtained for native proteins found in the PDB database (NATARAJ et al., 2009).

Peptide similarities for epitope sequences found in the studied allergens, measured as PD scores (Table 2), revealed that the sequences ARFLAEEADRKYD, ESKIVELEEELRVVG, QKLQKEVDRLEDELV, and RSLSDEERMDALENQ are totally identical (PD values of 0.0 ) in Pen a1, Cha f1, Hom al, and Met e1 suggesting possible cross-reactivity between these allergens. On the other hand, sequences such as EKYKSITDELDQTFS, ELVNEKEKYKSITDE, MQQLENDLDQVQESLLK, VDRLEDELVNEKEKY, and VHNLQKRMQQLENDL, although identical in Hom a1, Met e1, and Pen al are highly different in Chaf1, probably as a result of different evolutionally 
origin. Interestingly, some epitope sequences found in the studied allergens were identical to those found in allergens from other species. In the case of Pan s1 (Spiny lobster) and Lit v1 (Whiteleg shrimp), these similarities occur in 8 sequences suggesting a great cross-reactivity possibility.

The analysis of lipophilic potentials (LP) (Figure 2) showed the different distributions of hydrophobic residues that were more likely to be in these epitopes. The characterization of the two initial epitopes in the surface lipophilic potential revealed a patch of lipophilic residues, such as Leu, Met, Val, and Ile. These non-polar amino acids can be easily illustrated at the top of the helical-wheel. Sequences found in the three sequences located in the intermediate region of the allergen did not show a particular arrangement. However, some hydrophobic amino acids are still present, such as Leu, Met, Ile, Val, Ala, Tyr, and Phe together with some polar residues such as Asp, Glu, and Arg. The three superimposed epitope sequences found in the $\mathrm{C}$-terminal region of the allergen also have a relatively continue surface area of hydrophobic amino acids, but the LP area is smaller.

In conclusion, good quality three-dimensional structures of tropomyosins found in shellfish species were generated using a combination of bioinformatic tools. Several epitope sequences were detected within each allergen, and each one of them presented different structural features with some predominance of hydrophobic residues depending on their position in the sequence. These data are important to understand the nature of allergenicity reactions produced by proteins found in seafood, and they provide some basis for designing tropomyosin-specific immunotherapy for shellfish- and mollusks-derived foods.

\section{Acknowledgement}

The authors thank the Vice-Rectory for Research of the University of Cartagena for supporting this study. Nataly Galán-Freyle was the holder of "Virginia Gutierrez de Pineda Scholarship" (Grant P-2009-0327) granted by Colciencias (Bogotá, Colombia) and the University of Cartagena (Cartagena, Colombia).

\section{References}

ANURADHA, C. et al. Probing ligand Binding modes of Mycobacterium tuberculosis MurC ligase by molecular modeling, dynamics simulation and docking. Journal of Molecular Modeling, v. 16, p. 77-85, 2010. PMid:19484275. http://dx.doi.org/10.1007/s00894009-0521-2

AYUSO, R.; LEHRER, G. B.; REESE, G. Identification of continuous, allergenic regions of the major shrimp allergen Pen a 1 (tropomyosin). International Archives of Allergy and Immunology, v. 127, n. 1, p. 27-37, 2002. PMid:11893851. http:// dx.doi.org/10.1159/000048166

BREITENEDER, H.; MILLS, E. N. Molecular properties of food allergens. Journal of Allergy and Clinical Immunology, v. 115, n. 1, p.14-23, 2005. PMid:15637541. http://dx.doi.org/10.1016/j. jaci.2004.10.022

BRUSIC, V.; PETROVSKY, N. Bioinformatics for characterization of allergens, allernicity and allergic crossreactivity. Trends in Immunology, v. 24, n. 5, p. 225-228, 2003. http://dx.doi. org/10.1016/S1471-4906(03)00075-9
COLOVOS, C.; YEATES, T. Verification of protein structures: patterns of nonbonded atomic interactions. Protein Science, v. 2, n. 9, p. 1511-9, 1993. PMid:8401235. PMCid:2142462. http://dx.doi. org/10.1002/pro.5560020916

DAUL, C. B.; MORGAN, J. E.; LEHRER, S. B. Hypersensitivity reactions to crustacea and mollusks. Clinical Reviews in Allergy and Immunology, v. 11, n. 2, p. 201-22,1993.

EISENBERG, D.; LÜTHY, R.; BOWIE, J. Verify 3D: assessment of protein models with three dimensional profiles. Methods in Enzymology, v. 277, p. 396-404, 1997. http://dx.doi.org/10.1016/ S0076-6879(97)77022-8

FÁVERO, P. et al. Molecular modeling studies and in vitro bioactivity evaluation of a set of novel 5-nitro-heterocyclic derivatives as anti-T. cruzi agents. Bioorganic \& Medicinal Chemistry, v. 17, n. 7, p. 2673-2679, 2009. http://dx.doi.org/10.1016/j.bmc.2009.02.056

FEDOROV, A. et al. The molecular basis for allergen cross-reactivity: crystal structure and IgE epitope mapping of birch pollen profiling. Structure, v. 5, n. 1, p. 33-45, 1997. http://dx.doi.org/10.1016/ S0969-2126(97)00164-0

FERREIRA, F. et al. Modulation of IgE reactivity of allergens by sitedirected mutagenesis: potential use of hypoallergenic variantas for immunotherapy. The FASEB Journal, v. 12, p. 231-242, 1998. PMid:9472988.

HOOFT, R. W. W. et al. Errors in protein structures. Nature, v. 381, p. 272-272, 1996. PMid:8692262. http://dx.doi.org/10.1038/381272a0

IVANCIUC, O. et al. Using property based sequence motifs and 3D modeling to determine structure and functional regions in CASP5 targets. Current Medicinal Chemistry, v. 11, p. 583-593, 2004. PMid:15032606. http://dx.doi.org/10.2174/0929867043455819

IVANCIUC, O. et al. Detecting potential IgE-reactive sites on food proteins using a sequence and structure database, SDAP-Food. Journal of Agricultural and Food Chemistry, v. 51, n. 16, p. 4830-4837, 2003. PMid:14705920. http://dx.doi.org/10.1021/ jf034218r

JENKINS, J. A. et al. Structural Relatedness of plant food allergens with specific reference to cross-reactive allergens: an in silico analysis. Journal of Allergy and Clinical Immunology, v. 115, n. 1, p. 163-170, 2005. PMid:15637564. http://dx.doi.org/10.1016/j. jaci.2004.10.026

LASKOWSKI, R. et al. Procheck: a program to check the stereochemical quality of protein structures. Journal of Applied Crystallography, v. 26, p. 283-290, 1993. http://dx.doi.org/10.1107/ S0021889892009944

LEHRER, S. B.; MCCANTS, M. L. Reactivity of IgE antibodies with Crastacea and oyster allergens: evidence for common antigenic structures. Journal of Allergy and Clinical Immunology, v. 80, p. 133-139, 1987. http://dx.doi.org/10.1016/0091-6749(87)90121-7

LU, Y. et al. Immunological characteristics of monoclonal antibodies against shellfish major allergen tropomyosin. Food Chemistry, v. 100 , n. 3, p. 1093-1099, 2007. http://dx.doi.org/10.1016/j. foodchem.2005.11.015

MUSMAND, J. J.; DAUL, C. B.; LEHRER, S. B. Crustacean allergy. Clinical \& Experimental Allergy, v. 23 p. 722-32, 1993. http:// dx.doi.org/10.1111/j.1365-2222.1993.tb00359.x

NATARAJ, P. et al. Genome wide analysis and comparative docking studies of new diaryl furan derivatives against human cyclooxygenase-2, lipoxygenase, thromboxane synthase and prostacyclin synthase enzymes involved in inflammatory pathway. Journal of Molecular Graphics and Modelling, v. 28, n. 4, 
p. 313-329, 2009. PMid:19766029. http://dx.doi.org/10.1016/j. jmgm.2009.08.010

NATIONAL CENTER FOR BIOTECHNOLOGY INFORMATION - NCBI. National Library of Medicine. Disponível em: <http://www.ncbi.nlm.nih.gov/>. Acesso em: 25 set. 2010.

ROY, A.; KUCUKURAL, A.; ZHANG, Y. I-Tasser: a unified platform for automated protein structure and function prediction. Nature Protocols, v. 5, n. 4, p. 725-738, 2010. Disponível em: <http://zang. bioinformatics.ku.edu/I-TASSER/>. Acesso em: 17 out. 2010.

SAHA, S.; RAGHAVA, G. Algpred: prediction of allergenic proteins and mapping of IgE epitopes. Nucleic Acids Research, v. 34, n. 2, p. W202-W209, 2006. Disponível em: <http://www.imtech.res.in/ raghava/algpred/>. Acesso em: 09 nov. 2010.

SCHEIN, C.; IVANCIUC, O.; BRAUN, W. Common physical-chemical properties correlate with similar structure of the IgE epitopes of peanut allergens. Journal of Agricultural and Food Chemistry, v. 53, n. 22, p. $8752-8759$, 2005. PMid:16248581. http://dx.doi. org/10.1021/jf051148a

SCHEIN, C.; IVANCIUC, O.; BRAUN, W. Structural Database of Allergenic Proteins - SDAP. In: MALEKI, S. J.; BURKS, A. W.; HELM, R. M. (Ed.). Food Allergy. Washington: ASM Press, 2006. p. 257-283. Disponível em: <http://fermi.utmb.edu/SDAP/>. Acesso em: 07 nov. 2010.

SCHEIN, C.; IVANCIUC, O.; BRAUN, W. Bioinformatics Approaches to Classifying Allergens and Predicting Cross-Reactivity. Immunology And Allergy Clinics of North America, v. 27, n. 1, p. 1-27, 2007. PMid:17276876. PMCid:1941676. http://dx.doi. org/10.1016/j.iac.2006.11.005

SCHWEDE, T. et al. Swiss-Model: An automated protein homologymodeling server. Nucleic Acids Research, v. 31, n, 13, p. 3381-3385, 2003. Disponível em: <http://swissmodel.expasy. org/repository/?pid=smd03>. Acesso em: 12 out. 2010.

TRIPOS. 2008. Disponível em: <www.tripos.com>. Acesso em: 10 out. 2010

VENKATARAJAN, M.; BRAUN, W. New quantitative descriptors of amino acids based on multidimensional scaling of a large number of physical-chemical properties. Journal of Molecular Modeling, v. 7, n. 12, p. 445-453, 2001. http://dx.doi.org/10.1007/s00894-001-0058-5

WESTBROOK, J. et al. The Protein Data Bank and structural genomics. Nucleic Acids Research, v. 31, p. 489-491, 2003. PMid:12520059. PMCid:165515. http://dx.doi.org/10.1093/nar/gkg068

WIEDERSTEIN, M., SIPPL, M. ProSA-web: interactive web service for the recognition of errors in three-dimensional structures of proteins. Nucleic Acids Research, v. 35, n. 2, p. 407-10, 2007. PMid:17517781 . PMCid:1933241. http://dx.doi.org/10.1093/nar/gkm290

YANG, Q. et al. Modeling the binding modes of Kv1.5 potassium channel and blockers. Journal of Molecular Graphics and Modelling, v. 27, n. 2, p. 178-187, 2008. PMid:18485768. http:// dx.doi.org/10.1016/j.jmgm.2008.04.002

ZHANG, Y. I-Tasser server for protein 3D structure prediction. BMC Bioinformatics, v. 9, n. 1, p. 40, 2008. PMid:18215316. PMCid:2245901. http://dx.doi.org/10.1186/1471-2105-9-40 